\title{
PLURALISME HUKUM DALAM PENYELESAIAN KONFLIK PEMOTONGAN NISAN SALIB DI KAWASAN PURBAYAN KOTA GEDE YOGYAKARTA
}

\author{
Ismaya Dewi Priyani \\ Program Studi Magister Ilmu Hukum Pascasarjana, UIN Sunan Gunung Djati \\ Bandung, Indonesia \\ Email : priyaniismaya@gmail.com
}

Diterima : 2 April 2021, Revisi : 10 May 2021 Disetujui : 1 juni 2021

\begin{abstract}
ABSTRAK
Penelitian ini berangkat dari polemik terjadinya pemotongan nisan salib di kawasan Purbayan Kota Gede Yogyakarta. Dalam isu yang berkembang dimasyarakat, tindakan tersebut dianggap sebagai suatu perbuatan intoleran dalam beragama. Kemudian peneliti mengaitkan kasus tersebut dengan pluralisme hukum di Indonesia. Penelitian ini bertujuan untuk mengetahui konsep pluralisme hukum serta bagaimana pandangan para akademisi dalam menyikapi kasus pemotongan nisan salib tersebut. Peneliti mendapatkan data kualitatif dengan melakukan wawancara, menggunakan metode penelitian deskriptif analistis dan pendekatan kasus (case approach). Hasilnya bahwa konsep pluralisme hukum berkembang beriringan dengan munculnya pluralisme sosial. Pada masyarakat yang plural akan muncul pula hukum yang plural. Sentralisasi hukum menjadi percuma karena cenderung asosial. Pluralisme hukum menunjukan sistem hukum yang beragam dan berlaku bersamaan atau berinteraksi dalam mengatur berbagai aktivitas dan hubungan manusia di suatu tempat. Para akademisi yang menjadi narasumber, terhadap kasus pemotongan nisan salib di kawasan Purbayan Kota Gede Yogyakarta memiliki pandangan tindakan memotong nisan salib merupakan suatu bentuk intoleran. Kasus pemotongan nisan salib tersebut sebagai suatu cerminan keterbatasan pengaturan hukum sentral (skala nasional) dalam masyarakat yang plural. Kasus tersebut merupakan pelanggaran atas toleransi beragama di masyarakat.
\end{abstract}

Kata kunci: Pluralisme Hukum, Pluralisme Agama, Pluralisme sosial, Pemotongan Nisan Salib, Purbayan Kota Gede

\begin{abstract}
This research departed from the polemic of the cutting of the crossing headstone in the Purbayan City Gede area of Yogyakarta. In issues that develop in the community, these actions are considered as an intolerant act in religion. Then the researcher linked the case with legal pluralism in Indonesia. This study aims to determine the concept of legal pluralism and the views of academics in responding to the case of cutting the headstone. Researchers get qualitative data by conducting interviews, using descriptive analytical research methods and case approaches. The result is that the concept of legal pluralism evolves in tandem with the emergence of social pluralism. In a pluralistic society plural laws will emerge. The centralization of law is useless because it tends to be asocial. Legal pluralism shows a diverse legal system and applies together or interacts in regulating various human activities and relationships somewhere. The academics who were the speakers, in the case of cutting the headstone in the area of Purbayan Kota Gede Yogyakarta, had the view that cutting the headstone was a form of intolerance. The case of cutting the cross headstone as a reflection of the limitations of the central legal arrangement (national scale) in a pluralistic society. The case is a violation of religious tolerance in the community.
\end{abstract}


Keyword: Legal Pluralism, Religious Pluralism, Social Pluralism, Cutting the Tomb of the Cross, Purbayan Kota Gede

\section{PENDAHULUAN}

Bertambahnya komponen dalam hukum adalah ciri bahwa hukum telah berkembang, mulai dari perangkat hukum seperti aturan yang bersifat khusus (lex specialist), penegak hukum dan budaya hukum yang semakin berkembang (Is, 2016). Masyarakat telah menyesuaikan kebutuhannya dengan produk-produk hukum sebelumnya, di Indonesia telah berkembang dengan adanya hukum adat yang sudah ada dan lahir dari budaya masyarakat (Qadri, 2021). Menurut Soerjono Soekanto (1977), hukum adat adalah konkretisasi dari pada kesadaran hukum, khususnya pada masyarakat dengan struktur sosial dan kebudayaan sederhana. Hukum positif di Indonesia telah mengadopsi hukum adat tersebut untuk disesuaikan serta di implementasikan kedalamnya. Indonesia adalah negara dan suku yang beragam sehingga mengakibatkan keberagaman dalam paradigma hukum. Keberagaman dalam hukum ini dikenal dengan istilah pluraslisme hukum.

Pluralisme hukum terjadi bukan merupakan suatu masalah melainkan itu menjadi ciri khas dalam suatu norma atau aturan hukum yang berlaku di suatu kawasan dan wilayah tertentu di Indonesia (Ismi, 2012). Berkaitan dengan makna hukum tidak tunggal dalam kajian pluralisme hukum,memakai pemikiran segitiga Menski, yang membagi 3 (tiga) sudut pandang yakni sudut pandang negara; masyarakat; serta moral, etika dan religi dalam bingkai pluralisme hukum.

Dalam sudut pandang moral, etika dan religi (berada di sudut bagian atas segitiga), negara (pemerintah daerah) dalam membentuk peraturan perundang-undangan, harus mampu memadukan etika untuk menghargai perbedaan persepsi dengan masyarakat mengenai radius kawasan suci Pura, berdasarkan keyakinan yang mereka anut yang secara moral dengan menerapkan keadilan sosial yang transisional (adanya perbedaan antara satu tempat dengan yang lainnya) (Alia et al., 2020). Bentuk kebijakan 
apapun dari pemerintah menyangkut langsung atau tidak langsung dengan masyarakat adat harus dikomunikasikan hingga kebijakan dapat diterima tanpa ada pihak yang dirugikan (Wibawa, 2018). Saling melengkapinya antara, hukum adat (kearifan lokal) . Dalam artian lain, hukum tata ruang di bangun oleh beberapa jenis hukum yang berbeda yang kemudian berinteraksi saling melengkapi antara satu dengan yang lainnya (Zakiyah, 2019). Hal itu diperlukan untuk menghindari terjadinya pertarungan politik hukum negara dan politik kebudayaan, akibatadanya terjadi tarik menarik antara kepentingan negara (pemda) melalui instrument hukumnya dengan desa adat yang memiliki karakter hukum desa, kala, patra, desa mawacara (Izad, 2020).

Dalam kasus keberagaman hukum dalam masyarakat seperti contoh kecil nya yang telah terjadi di Purbayan Kotagede Yogyakarta dimana nisan salib makam Albertus Slamet Sugihardi dipotong bagian atasnya oleh warga. Meski warga menyebut sudah ada kesepakatan atas pemotongan itu dan keluarga disebut ikhlas, akan tetapi hal ini tetap jadi perbincangan banyak orang. Pemotongan nisan salib itu terjadi Senin (17/12/2018). Ketua RW 13 Selamet Riyadi menyebut pemotongan dilakukan oleh pengurus makam setelah adanya kesepakatan antara warga, pihak gereja, hingga keluarga almarhum. Lurah Purbayan, Suradi, mengatakan tanah yang digunakan sebagai pemakaman Albertus merupakan tanah turun temurun yang dikelola oleh masyarakat sekitar.

Ada dua jenis pemakaman berdasarkan Peraturan Daerah (Perda) Kota Yogyakarta Nomor 7/1996. Pertama adalah Tempat Pemakaman Umum yang disediakan untuk setiap orang tanpa membedakan agama dan golongan. Ini dikelola Pemerintah Daerah. Kedua adalah Tempat Pemakaman Bukan Umum yang pengelolaannya dilakukan oleh Badan Sosial dan atau Badan Keagamaan. Menurut Suradi, makam di Purbayan tidak tergolong ke dalam keduanya. Maka dari itu pengelolaannya diserahkan ke pengurus kampung Nisan salib di makam seorang warga bernama Albertus Slamet Sugihardi dipotong bagian atas oleh warga RT 53 
RW 13, Purbayan, Kotagede. Pemotongan salib dan larangan misa arwah itu dilakukan untuk "menghindari konflik." Rumah Slamet pernah didatangi warga karena menggelar sembahyang lingkungan. Saat itu ia meredakan amarah warga dan meminta warga Katolik untuk tidak lagi menggelar sembahyang di kampung. Mantan Ketua RW setempat ini menolak jika warga disebut "intoleran". Menurutnya, mereka sudah cukup toleran dengan tetap membolehkan Slamet dimakamkan di tempat yang 99 persennya adalah orang Islam.

Namun apakah menurut para akademisi peristiwa tersebut sudah ada unsur toleransi dalam beragama dan apakah hal tersebut mengenyampingkan pancasila Negara tentunya bukan soal tentang agama tapi tentang kemanusiaan. Dari penjabaran berikut penulis tertarik untuk membahas terkait Pluralisme Hukum Dalam Penyelesaian Konflik Pemotongan Nisan Salib Di Kawasan Purbayan Kota Gede Yogyakarta.

\section{METODE PENELITIAN}

Penelitian ini dibuat oleh penulis terkait dengan pluralisme hukum yang berkembang di masyarakat khususnya kawasan Purbayan Kota Gede Yogyakarta. Penelitian ini bersifat deskriptif analisis, yaitu suatu penelitian yang mempunyai tujuan untuk menggambarkan dan menganalisis faktafakta yang secara sistematis, faktual dan akurat dengan teori-teori dan praktek pelaksanaan (Sadiah, 2015). Dalam penelitian ini peneliti mendapatkan data kualitatif dengan melakukan wawancara serta menggambarkan kasus secara sistematis mengenai fakta-fakta dalam kasus pemotongan nisan salib di kawasan Purbayan Kota Gede Yogyakarta serta hubungannya dengan pluralisme hukum dan kemudian dianalisis. Penelitian ini menggunakan metode pendekatan kasus (case approach) (Sugiyono, 2011).

Analisis data sekunder dan data primer yang diperoleh dari penelitian yang sifatnya deksriptif analisis dilakukan secara kualitatif melalui kesimpulan yang ditarik oleh peneliti dari hasil penelitian. secara kualitatif karena informasi-informasi yang didapat melalui wawancara yang 
disampaikan oleh narasumber dan data-data yang berhubungan langsung dengan permasalahan.

\section{HASIL DAN PEMBAHASAN}

Menurut Griffiths dalam Hasanah, Hamzah and Ikhwan (2018), pluralisme daadalah hukum yang berkonsep dengan isi prinsip dan substansi yang lebih dari satu, dan melihat suatu siatuasi atau keadaan dengan perbedaan sosial dan fakta yang ada. Pluralisme hukum terdapat pilihan dalam implementasi hukum. Pilihan yang harus dipelajari seperti sebuah perilaku khususnya dalam masalah penyelesaian sengketa dalam suatu masyarakat. Dalam urusan konflik selalu terdapat beberapa kemungkinan untuk menyelesaikan suatu masalah (Fuadi, 2020). Peradilan resmi yang dilakukan oleh aparat penegak keadilan dari negara atau adanya pilihan yang lain yang sangat luas seperi adanya mediasi para pihak dan juru runding.

\section{Pandangan Akademisi terhadap Kasus Pemotongan Nisan Salib Di Kawasan Purbayan Kota Gede Yogyakarta}

Kasus pemotongan nisan salib yang terjadi di Kawasan Purbayan Kota Gede Yogyakarta telah menjadi kasus yang menjadi sorotan publik dalam skala nasional. Terlebih lagi kasus tersebut terjadi ditengah maraknya isu berkaitan dengan sara di masyarakat. Peneliti telah melakukan mini riset untuk mendapatkan data kualitatif melalui wawancara dengan beberapa narasumber yang berasal dari kalangan akademisi untuk mengetahui bagaimana pandangan narasumber terkait dengan kasus pemotongan nisan salib di kawasan Purbayan Kota Gede Yogyakarta. Peneliti mengajukan beberapa pertanyaan sebagai berikut:

1. Apa pandangan saudara tentang pluralisme hukum?

2. Apa pentingnya pluralisme hukum diterapkan?

3. Indonesia adalah salah satu negara yang mengakui pluralisme hukum. Terkait dengan hal tersebut, bagaimana pendapat saudara tentang pengaturan dan penegakan hukum di Indonesia? 
4. Menurut saudara bagaimana idealnya toleransi dalam beragama, adat suku maupun budaya dilakukan?

5. Bagaimana masyarakat menjalankan hukum yang sesuai dengan pancasila?

6. Bagaimana menurut saudara pengaturan tentang toleransi beragama, suku maupun berbudaya di Indonesia?

7. Pasal 28E ayat (2) UUD 1945 yang menyatakan bahwa "setiap orang berhak atas kebebasan meyakini kepercayaan.” Bagaimana efektivitas pasal tersebut di Indonesia yang Plural?

8. Belakangan ini terjadi tentang nisan salib yang di potong di TPU umum oleh warga muslim dengan alasan TPU itu akan di jadikan TPU muslim dan 1 mayoritas disana orang muslim)

9. Bagaimana sikap saudara sebagai akademisi untuk menengahi masalah tersebut? (sesuai dengan keilmuan)

Berdasarkan hasil wawancara baik secara langsung maupun melalui pesan singkat pada tanggal 3 Januari 2019, para narasumber memberikan tanggapan sebagai berikut:

1. Yulia Sifa Insani, S.E "Menurut saya itu intoleran, karena ketika menjalankan agama "lakum diinukum waliyadin" maksudnya ketika hal itu salah kita sampaikan itu salah, dakwah kita hanya menyampaikan, bukan malah melakukan perbuatan yang memecah belah persatuan. Jelas dalam hal ini mengabaikan nilai pancasila poin persatuan indonesia."

2. Rahayu Eka, S.P.d "Menurut saya perbuatan tersebut menunjukan tidak ada toleransi karena dalam Islam sendiri sudah di jelaskan "lakum dinukum waliya diin", Karenakan Nabi pun dengan pamannnya Abu Tholib hidup rukun berdampingan, dan pada dasarnya Islam tidak memaksa manusia untuk masuk Islam, selama yang beda agamanya itu tidak ikut campur dalam agama Islam dan mengancam."

3. Firda Qotrunnada, S.P.d "Nisan salib, yang meninggalnya non 
muslim. Hal tersebut merupakan sikap intoleran. Walaupun mislanya sekitar 99\% muslim tetapi kan yang 1\% juga tetap warga negara yang harus dilindungi haknya. Toh tidak akan mengganggu iman yang muslim, kecuali kuburan tersebut merupakan kuburan khusus untuk muslim.”

4. Hera Siti S,A.p "Menurut pendapat saya ada dua pandangan, pertama mayoritas tidak menghargai bahkan tidak toleransi pada kaum minoritas, padahal sudah jelas bahwa di Indonesia terdapat berbagai macam suku ras dan budaya. Bahkan dalam pengertian pluralisme agama adalah suatu sebuah konsep yang memiliki makna yang luas yaitu penerimaan terhadap agama-agama yang berbeda salah satunya toleransi agama agar hidup lebih harmonis antar berbagai pemeluk agama. Kedua, memang itu pemakaman umum karena di Purbayan mayoritasnya orang muslim, kaum mayoritas juga ingin dihargai oleh kaum minoritas juga memakai batu nisan yang biasa saja mungkin dengan memakai batu nisan yang biasa aja akan terlihat saling menghargaai antar agama."

5. Risna Amanda, S.Hum "Tindakan tersebut tidak mencerminkan toleransi agama. Baik berdasarkan ketetapan toleransi dalam undang-undang yang tercantum dalam UUD (Pasal 28 ayat (2) mohon dikoreksi) yang mendasari toleransi dalam beragama. Kemudian, dalam hukum Islam pun, umat Islam dilarang untuk mencela agama lain, dalam bentuk apapun. Ada dalil yang menyatakan "dan janganlah kamu menghina tuhan-tuhan mereka”. Sebab sikap mencela dengan berbagai macam perilaku tidak dibenarkan dan dicontohkan oleh Al-Qur'an dan As-Sunnah, pun tidak dicontohkan oleh Rasulullah SAW. Bahkan menurut saya, idealnya, dengan penduduk yang mayoritas umat muslim seperti itu, pemahaman dan wajah Islam itu harus ditampakkan sebenarbenarnya, seperti bagaimana? Tentu seperti yang dicontohkan oleh Rasulullah dalam hal bersosialisasi, terutama dengan agama lain. 
Intinya, sikap seperti itu tidak mencerminkan sikap toleransi yang ideal dalam Islam, apalagi dengan alasan bahwa penduduk di daerah tersebut mayoritas muslim.

6. Afni Fauziah, S.Kom "Tidak ada yang salah dari perbuatan tersebut, karena sebelum dimakamkan sudah diketahui bahwa jenazah dimakamkan di TPU muslim. Tetapi jika ternyata pemotongan tersebut dilakukan secara spontanitas tanpa adanya mediasi terlebih dahulu dengan pemuka agama Kristen, hal tersebut menodai nilai Pancasila. Kan pada sila ke-4 berkaitan dengan musyawarah mufakat. Ada apa-apa harus dibicarakan dan disepakati. Jangan langsung motong tanpa mediasi. Lain ceritanya jika TPU tersebut akan dijadikan TPU muslim dan diketahui oleh umat Kristiani sekitar, tetapi tetap memaksakan untuk dimakamkan ditempat tersebut. Akan lain kesimpulannya."

7. Indriani Chandra, S.Sy. "Pada intinya, pluralisme adalah keberagaman. Hukum yang mengatur tentang keberagaman, bisa suku, ras bahkan agama. Pluralisme tersebut adalah upaya untuk menindak dan melindungi perbedaan. Agar tidak terjadi "saling hina loncat pagar" sehingga setiap umat beragama merasa aman dan nyaman tinggal di Indonesia. Penerapan hukum Indonesia sudah bagus jika tidak “tajam ke bawah dan tumpul ke atas”. Saling menghormati antar suku dan agama adalah tindakan yang penting, juga hubungan antar sesama manusia perlu di jaga. Jika menengahi berarti harus ada di tengah, jadi harus di cari tahu dulu latar belakang pemotongannya itu. Apa benar karena sekedar simbol atau hal yg lain."

8. Indra Hadi Surya, S.H. "Tindakan tersebut merupakan perbuatan intoleran dan mengabaikan nilai-nilai Pancasila, karna sudah jelas dalam sila pertama, yang mana sila tersebut merupakan hasil perubahan dari piagam Jakarta. Intinya di Indonesia itu hidup berdampingan berbeda agama saling menghormati karena jika 
dilihat sejarah agama yang pertama ada di Indonesia bukan Islam melainkan Hindu Budha."

9. Silma Nurhaurima, S.H. “ Menurut saya kepentingan diterapkannya pluralisme hukum itu untuk membentuk/menerapkan aturanaturan kepada wilayah yang memiliki perbedaan dalam suku, bahasa, budaya, agama dan ras. Contohnya adalah Indonesia sebagai suatu pedoman dalam kehidupan sosial masyarakat dalam wilayah tersebut sehingga tercipta keselarasan hidup serta keadilan sosial. Jika Indonesia mengakui adanya pluralisme hukum, kenapa pengaturan dan penegakan hukum di Indonesia menurut saya bisa dikatakan jauh dari kata adil. Jika masyarakat mengerti tentang pluralisme hukum bahkan sampai ke orang awam hukum sekalipun, di Indonesia sekarang tidak akan terjadi kericuhan, permusuhan, adu domba, penghinaan dan lain sebagainya. Ini dikembalikan lagi kepada pemerintah untuk lebih tegas lagi dan memberikan pengarahan tentang pluralisme hukum itu sendiri. Idealnya menurut saya dalam toleransi agama, suku dan budaya, lakukan itu harus sesuai dengan keyakinan yang masing-masing anut dan saling menghargai serta menghormati keputusan/jalan hidup yang masingmasing jalani. Seperti terjemahan ayat Al-Qur'an yang saya percaya dimana berbunyi "agamaku adalah agamaku dan agamamu adalah agamamu", bermacam budaya dan suku tidak menjadikan kita sebagai warga Indonesia sempit, sebaliknya menjadi luas akan ilmu dan malah berpositif menjadikan Indonesia kaya budaya seperti yang tercantum dalam pita burung garuda "Bhineka Tunggal Ika". Sikap saya tidak akan terbawa cepat dengan isu tersebut, sebagai seorang sarjana alangkah baiknya memiliki sikap yang tenang dan jeli menghadapi sesuatu segalanya harus ditelusuri lebih dalam. Namun saya percaya jika dia mengaku sebagai orang yang benarbenar menganut agama Islam tindakannya tidak akan seperti itu. Itu merupakan suatu tindakan kriminal dan tidak patut di contoh jauh 
dari kata terpuji, tidak manusiawi dan berpikir dangkal. Apasalahnya dari orang yang sudah meninggal, toh mereka juga mempunyai keluarga. Sesama muslim bahkan yang tidak seagamapun org islam mengganggapnya sebagai saudara."

10. Hervina Dwi Yuniar, S.H. "Pluralisme hukum merupakan gabungan dari sistem hukum yang berlaku di Indonesia dimana ketiga sistem hukum yg diterapkan di indonesia memiliki kesamaan didalemnya dengan tujuan tecapainya keadilan dan kemaslahatan bagi seluruh kalangan warga negara indonesia. Peraturan hukum di indonesia pada dasarnya sudah sesuai dengan asas-asas yang terkandung dalam nilai Pancasila hanya saja saat ini dalam penegakannya masih sangat dirasakan lemah bagi beberapa pihak. Apalagi di era milenial ini seharusnya muncul aturan hukum yang mengikuti perkembangan jaman dengan penafsiran yang jelas sehingga tidak menimbulkan berbagai opini dikalangan masyarakat tentang aturan hukum tersebut. Idealnya toleransi dalam beragama, suku maupun budaya seharusnya timbul dari kesadaran setiap individu. Peran pemimpin atau tokoh dari suatu lingkungan atau daerah akan sangat berpengaruh bagi munculnya sifat toleransi dalam ketiga hal tersebut. Ketika pemimpin atau tokoh dapat mengayomi masyarakat sekitarnya tentang pentingnya toleransi, maka nantinya masyarakat pun dapat menanamkan jiwa toleransi tersebut dilingkungan sekitarnya. Yang terpenting itu pendidikan tentang toleransi yang didapat dari keluarga. Pengaturan tentang adanya toleransi beragama suku dan budaya di Indonesia pada dasarnya lahir dari historis berdirinya culture di masing-masing daerah. Dimana sebenarnya sikap toleransi tersebut sudah menerapkan nilai-nilai yang terkandung dalam Pancasila, hanya saja belakangan ini sering terjadinya sikap masyarakat yang menjurus ke arah intoleransi dikarenakan oknum masyarakat tersebut ingin menonjolkan culture asli dari daerah tersebut dengan cara menolak hadirnya culture baru 
yang menurut mereka tidak sesuai dengan kepribadian. Terkait isu intoleransi yang belakangan ini terjadi di Indonesia, menurut saya aturan yang sudah berlaku terkait intoleransi harus lebih ditegaskan dalam penegakannya dan jika memang diharuskan untuk membuat aturan baru terkait hal tersebut seharusnya pemerintah bertindak cepat agar masyarakat memiliki batasan-batasan tertentu dalam bersikap toleransi terhadap sesama.”

11. Saeful Bahri,S.H "Pendapat saya terkait contoh kasus diatas jelas tidak mencerminkan toleransinya dalam beragama. Karena tempat pemakaman tersebut temasuk pemakamam umum. Jadi siapapun berhak di tempatkan di sana. Selagi si keluarga yang di makamkan tersebut warga desa dan memenuhi persyaratan administrasi warga setempat. Hukum kita kan melindungi setiap hak perorangan dan ruang lingkup pemakam itu tanah publik bukan tanah milik perseorangan. Kecuali di TPU nya ada peraturan yang tidak membolehkan memakai simbol apapun. Termasuk simbol muslim. Kalau hanya tidak membolehkan simbol akan terlihat membedabedakannya. Sedangkan dalam Pancasila, pada sila kelima kan ada keadilan sosial bagi seluruh rakyat Indonesia, maka jika kelompok tersebut dilarang menggunakan simbol kepercayaannya itu tidak adil bagi mereka."

12. Ferdian Hanif Dw, S.H "Pluralisme hukum merupakan suatu ragam hukum disuatu wilayah, ketika diwilayah tersebut sudah ada hukum yang berlaku lingkup kelompok kemudian dihadapkan oleh hukum lain namun berlaku juga bagi wilayah tersebut, singkatnya hukum adat dihadapkan pada hukum nasional baik Perda maupun Undangundang. Terlepas dari masalah ketimpangan maupun tumpang tindihnya hukum, pluralisme hukum penting untuk tetap ada, hal ini guna menjamin terlaksananya Pasal 18B ayat (2) UUD 1945, yang menyatakan bahwa Negara mengakui serta menghormati kesatuankesatuan masyarakat hukum adat beserta hak-hak tradisionalnya 
sepanjang masih hidup dan sesuai dengan prinsip Negara Kesatuan Republik Indonesia. Terkait dengan pengaturan hukum yang plural di Indonesia sudah cukup baik, karna untuk menemukan hukum yang ideal yaitu hukum yang bersifat netral dan dapat diakui secara nasional tanpa terkecuali akan sangat sulit. Kita ketahui Indonesia memiliki daerah-daerah yang istimewa, contoh Aceh. Di Aceh kita mengakui adanya hukum yang erat kaitannya dengan syari'at Islam, tentu tidak dapat dipaksakan untuk diberlakukan pada daerah lain, begitu pula sebaliknya. Yang masih sering menjadi masalah adalah penegakan hukum. Pada praktiknya para Aparat Penegak Hukum seperti hakim, tidak selalu menggali nilai-nilai yang hidup dan berkembang di masyarakat. Melainkan hanya menjadi "corong Undang-undang". Hal tersebut tentu tidak akan memenuhi nilai keadilan bagi masyarakat. Bagi saya, idealnya toleransi dalam beragama, adat, suku maupun budaya hanya dilakukan sebatas memberi edukasi terkait bagaimana agama $\mathrm{A}, \mathrm{B}$ atau $\mathrm{C}$, bagaimana adat $\mathrm{A}, \mathrm{B}$ atau $\mathrm{C}$, begitu pula dengan suku maupun budaya, tanpa harus memaksakan orang lain untuk ikut andil membangun agamanya, adatnya, suku maupun budayanya. Karena itu ranah pribadi masing-masing atau lingkup golongan masing-masing. Masyarakat yang tidak menganut agama tersebut biarkan untuk cukup mengetahui agar dapat menghargai. Dalam Islam diajarkan "lakum diinukum wa liya diin" yang artinya bagimu agamamu, bagiku agamaku. Saya yakin agama lain pun mengajarkan demikian. Adat, suku dan budaya juga demikian, misalnya orang Jawa, tumbuh berkembang di Jawa, bertempat tinggal di Jawa, kemudian disuruh untuk mencerminkan adat, suku maupun budaya Batak atau budaya Minang, saya rasa akan sulit karena tentu antara adat, suku dan budaya Jawa, Batak dan Minang memiliki perbedaan dan ciri khas masing-masing. Jadi baiknya hanya sekedar edukasi. Hukum hari ini tentu tidak jauh dari butir-butir Pancasila, meskipun pada 
kenyataannya dijalankan belum seperti apa seharusnya (idealnya) namun sudah cukup baik, hanya terlalu banyak aturan yang belum dimengerti serta media cetak maupun elektronik yang kurang edukatif sehingga masyarakat masih sering keliru dalam menerapkan suatu aturan. Jika melihat kepada Pancasila, seharusnya pengaturan tentang toleransi beragama, suku maupun berbudaya di Indonesia sudah cukup baik. Pasal 28E ayat (2) UUD 1945 masih terlalu luas, tentu hal ini perlu dimuat dalam peraturan perundang-undangan yang konkrit dan tidak melebar, yang menyatakan bahwa kepercayaan seperti apa yang diakui agar tidak multitafsir, pasal tersebut menjadi polemik di tahun 2017 bahwa di KTP terdapat kolom agama tidak ada kolom kepercayaan sedangkan dalam UUD dinyatakan demikian. Kasus pemotongan nisan salib di TPU harus disikapi dengan bijaksana. Kasus tersebut dapat dipandang sudah clear, karena dari pihak keluarga pun tidak masalah untuk nisannya dipotong dan pemotongan pun dilakukan setelah adanya mediasi antara pemuka agama, pejabat setempat dengan pihak keluarga. Namun saya menyayangkan keinginan pihak keluarga untuk menggunakan salib sebagai nisan, seharusnya sedikit banyak pihak keluarga mengerti lingkungan tempat tinggalnya adalah lingkungan mayoritas beragama muslim, jika memang tetap ingin menggunakan nisan dengan simbol keagamaan seharusnya keluarga memakamkan pada TPU yang khusus untuk umat Kristiani. Hal ini akhirnya benar saja, memojokan umat muslim dan munculah isu intoleran. Masyarakat awam akan menyatakan intoleran karena tidak menegaskan batasan-batasan toleransi."

Dari hasil wawancara tersebut diatas dapat disimpulkan bahwa sebagian besar narasumber memiliki pandangan, tindakan memotong nisan salib yang dilakukan oleh masyarakat di kawasan Purbayan Kota Gede Yogyakarta merupakan suatu bentuk intoleran. Narasumber yang memiliki latar belakang pendidikan hukum berpandangan bahwa kasus pemotongan 
nisan salib tersebut sebagai suatu cerminan keterbatasan pengaturan hukum nasional dalam masyarakat yang plural. Sedangkan narasumber yang memiliki latar belakang pendidikan lainnya berpandangan bahwa kasus tersebut merupakan pelanggaran atas toleransi beragama di masyarakat.

Dilihat dari letak geografis dan historisnya Kotagede artinya 'kota besar'. Ia disebut demikian karena punya sejarah ratusan tahun yang sangat penting, yaitu sebagai ibu kota pertama Kesultanan Mataram. Bekas istana Mataram ada di Kotagede. Makam Panembahan Senopati, raja pertama Mataram, pun ada di Kotagede. Kesultanan Mataram bukan cuma pusat pemerintahan, melainkan juga pusat spiritual Islam pada zamannya. Kotagede bukan wilayah yang besar. Secara administratif, ia sekarang menjadi kecamatan, dengan luas cuma 3,07 km persegi. Itu pun sudah termasuk area-area yang ditambahkan, melebihi Kotagede yang asli, yang merupakan bekas ibukota Mataram itu. "Kotagede asli” lebih sempit dari Kecamatan Kotagede Purbayan, kampung TKP peristiwa itu, merupakan bagian dari Kotagede asli, Kotagede kuno. Jaraknya hanya sekitar satu kilo dari makam Panembahan Senopati.

Bagi masyarakat Kotagede, Islam bukan hanya setara dengan Islamnya masyakarat urban di kota-kota (NAKAMURA, 2019). Maksudnya, Islam memang sama-sama agama. Namun, di Kotagede, ia menjadi identitas melekat semacam “adat”. Ibaratnya, kalau orang Bali akan utuh menjadi Bali hanya jika ia Hindu, orang Kotagede rasanya kurang sempurna meng-Kotagede jika ia bukan muslim.

Dengan sosiologi masyarakat seperti itu, juga dengan warisan sejarah istimewa itu (Gangopadhyay, 2021), Kotagede itu ibarat sebuah kampung adat. Memang tidak ada stempel administratif sebagai kampung adat, tapi kampung-kampung adat di mana-mana itu sebenarnya juga tidak butuh stempel. Kotagede sangat lekat dengan Islam, selama ini masyarakat aslinya juga 100 persen muslim (keluarga almarhum yang beragama Katolik itu merupakan warga pendatang meski sudah lama di Kotagede), dan 
KHAZANAH MULTIDISIPLIN

VOL 2 NO 22021

https://journal.uinsgd.ac.id/index.php/kl

selama ratusan tahun makam-makam di daerah itu hanya diisi dengan jenazah muslim. Tidak semua penyikapan berbeda berdasar agama bisa dengan mudahnya di anggap sebagai sikap intoleran (Jalil, 2016). Di sinilah para aktivis keberagaman dituntut untuk tidak semata menerapkan ayatayat suci pluralisme secara tekstual.

\section{SIMPULAN}

Konsep pluralisme hukum berkembang beriringan dengan munculnya pluralisme sosial. Pada masyarakat yang plural akan muncul pula hukum yang plural. Sentralisasi hukum menjadi percuma karena cenderung asosial. Pluralisme hukum menunjukan sistem hukum yang beragam dan berlaku bersamaan atau berinteraksi dalam mengatur berbagai aktivitas dan hubungan manusia di suatu tempat. Para akademisi yang menjadi narasumber, terhadap kasus pemotongan nisan salib di kawasan Purbayan Kota Gede Yogyakarta memiliki pandangan tindakan memotong nisan salib merupakan suatu bentuk intoleran. Kasus pemotongan nisan salib tersebut sebagai suatu cerminan keterbatasan pengaturan hukum sentral (skala nasional) dalam masyarakat yang plural. Kasus tersebut merupakan pelanggaran atas toleransi beragama di masyarakat.

\section{DAFTAR PUSTAKA}

Alia, S. et al. (2020) "Budaya Lembaga Pendidikan sebagai Pilar Utama Melawan Degradasi Moral,” Khazanah Pendidikan Islam, 2(2), pp. 84-89.

Fuadi, S. H. (2020) "Resolusi Konflik Sosial Perspektif Hukum Islam dan Hukum Adat pada Pemilihan Kepala Desa Bajang Mlarak Ponorogo," AL-MANHAJ: Jurnal Hukum dan Pranata Sosial Islam, 2(1), pp. 86111.

Gangopadhyay, M. (2021) "VALUES AND PSYCHOLOGICAL WELLBEING OF YOUTH: A SUSTAINABLE INTERCONNECTION," Khazanah Pendidikan Islam, 3(1), pp. 30-40.

Hasanah, U., Hamzah, M. A. and Ikhwan, M. (2018) "Pluralisme Hukum Dalam Penyelesaian Sengketa Warisan Pada Masyarakat Madura," Arena Hukum, 11(1), pp. 163-183.

Is, M. S. (2016) Hukum Perusahaan di Indonesia. Prenada Media. 
KHAZANAH MULTIDISIPLIN

VOL 2 NO 22021

https://journal.uinsgd.ac.id/index.php/kl

Ismi, H. (2012) "Pengakuan dan perlindungan hukum hak masyarakat adat atas tanah ulayat dalam upaya pembaharuan hukum nasional," Jurnal Ilmu Hukum, 3(1).

Izad, R. (2020) "Konstruksi Nalar Teologi Politik Fundamentalisme Islam dalam Perspektif Epistemologi Bayani Muhammad Abid Al-Jabiri,” Khazanah Theologia, 2(3), pp. 132-141.

Jalil, A. (2016) "Dakwah MMI (Mengurai Kekerasan Sosial pada Diskusi di LKiS Yogyakarta)," al-Balagh: Jurnal Dakwah dan Komunikasi. Fakultas Ushuluddin dan Dakwah IAIN Surakarta, 1(1), pp. 1-22.

NAKAMURA, M. (2019) "Prof. H. Abdul Kahar Muzakkir dan Perkembangan Gerakan Islam Reformis di Indonesia," Jurnal AFKARUNA Vol, 15(2).

Qadri, A. (2021) "Bencana dan Tindakan Kepedulian Sosial dalam Keberagamaan: Studi Komparasi Kitab Suci al-Qur'an dan Alkitab,” Khazanah Theologia, 3(2), pp. 105-116.

Sadiah, D. (2015) Metode Penelitian Dakwah: Pengantar Kualitatif dan Kuantitatif. Bandung: Remaja Rosdakarya.

Soekanto, S. (1977) "Kesadaran hukum dan kepatuhan hukum," Jurnal Hukum \& Pembangunan, 7(6), pp. 462-470.

Sugiyono, P. (2011) "Metodologi penelitian kuantitatif kualitatif dan R\&D," Alpabeta, Bandung.

Wibawa, I. P. S. (2018) "Hukum Tidak Tunggal: Potret Pluralisme Hukum dalam Pengaturan Kawasan Tempat Suci Pura Uluwatu di Bali," Dharmasmrti: Jurnal Ilmu Agama dan Kebudayaan, 18(1), pp. 4553 .

Zakiyah, Z. (2019) "Moderasi Beragama Masyarakat Menengah Muslim: Studi Terhadap Majlis Taklim Perempuan di Yogyakarta," Harmoni, 18(2), pp. 28-50. 